\title{
EDITORIAL
}

\section{In Search of Health - The RAMC Contribution to APRE}

Man is the first weapon. This stark and perhaps rather depressing truth sets the scene for the Army Medical Services. Most of its medical work is therefore devoted to treating the consequences of illness, injury and battle. However, it also has a responsibility to ensure that the fighting man is fit to do his job. It is a small part of the history of this latter function which is described in this article.

On 1 April 1995 the Army Personnel Research Establishment (APRE) at Farnborough was formally incorporated into the Defence Research Agency (DRA) Centre for Human Sciences (CHS). This created a triService, human factors, research organisation designed to provide Ministry of Defence (MoD) with a more appropriate and responsive service. The future will be both challenging and uncertain. The intention here however, is to look backwards rather than forwards.

Exactly 30 years ago, on 1 April 1965, APRE was formed. Colonel Tom Carrick, Late RAMC, was its first and, as it happens, only military Director. It was created as an independent establishment for research into all aspects of man in the Army. The research therefore encompassed selection and training, ergonomics, clothing and equipment, environmental physiology and human trials. This Editorial will concentrate exclusively on the contribution by RAMC personnel, which, in the main, has been in the field of environmental physiology.

APRE was created by combining the Human Factors Division of the Army Operational Research Establishment (AORE) at West Byfleet with what had been the Clothing and Equipment Physiological Research Establishment (CEPRE) at Farnborough. They were not physically brought together until 1972 when the West Byfleet group moved to Farnborough and occupying temporary buildings until 1976 when a major rebuild began.

AORE and CEPRE, the two constituent parts of APRE had in fact been working together since 1963. At West Byfleet in AORE during that period were Lieutenant Colonel Joe Crowdy and Captain Dick Allan. The former remained within APRE until 1973 when he went on to complete a distinguished career within the RAMC. The later left the newly formed unit in 1965 and went to the Institute of Aviation Medicine, returning as the sixth and last Director of APRE in January 1990. Their principal research projects were concerned with heat acclimatization and, in particular, artificial acclimatization to heat; human water requirements in hot environments; human nutrition in arduous conditions and foot blistering.

In early 1971 Lieutenant Colonel David Worsley jointed Lieutenant Colonel Crowdy at West Byfleet, in what was called NEFA (nutrition, energy expenditure, fitness and acclimatization), eventually taking over from him when the latter was posted in 1973. The appointment was titled the Head of Applied Physiology and Field Trials (APFT) on the move to Farnborough.

During Lieutenant Colonel Worsley's tenure which ended in 1977, a number of medical officers passed through the unit, namely Majors Charles French, Ewan Thomas and Alec Grieve. All were attached to short periods of about a year and collectively continued to work on the areas of nutrition, energy expenditure, fitness and acclimatization. Concurrently within another part of APRE Captain Nigel Ince worked mainly on clothing physiology. In support of these RAMC Medical Officers were one or two laboratory technicians or hygiene assistants and a medical assistant providing day to day cover for the field trials team.

Lieutenant Colonel Tony Harwood relieved Colonel Worsley in 1977, by which time the appointment was known as Head of Applied Physiology A. He continued the tradition of long tenure and remained in post until 1988. During this time there was a shift in emphasis from research related to moving large numbers of troops around the world, particularly the warmer parts, to tho challenges of general war in North West Europe and the pressures imposed by domestic legislation, such as th@ Health and Safety at Work Act. At the same time the ability to analyse data electronically replaced the variouge manual, mechanical and valve driven procedures that had lasted up until the late 70's.

The change of emphasis was illustrated by the creatiom of the Army Occupational Health Research Un (AOHRU). This consisted of Lieutenant Colonel Harwood, a laboratory technician (Sergeant David Manser followed by Corporal Bill Parmar), a combat medical technician (Corporal Johnson) and a cook, who had no catering duties, but was inherited from previous nutritional trials. The emphasis of work shifted to include the assessment of toxic exposures in military training, particularly lead. The practical laboratory work involved in this was eventually moved to the Environmental Monitoring Team at Keogh Barracks. The traditional interest in fitness continued with work directed at the over $40 \mathrm{~s}$.

At the same time the teaching and training of RAMC officers was enhanced. In 1982 the Post Graduate Medical Officers' (PGMO) course began to spend one week at APRE. They were taught the important operational problems of cold, heat, noise and exercise. It was perhaps no coincidence that this positive step was taken when Brigadier Joe Crowdy was the Director of Army Preventive Medicine and Colonel David Worsley the Parkes Professor of Preventive Medicine. Both knew the value of exposing RAMC medical officers to the relevance of APRE's work early in their training.

The emphasis on postgraduate medical training, 
particularly in research, was shown by the increasing number of RAMC officers who were attached to AOHRU. Attachments were often for quite short periods and linked to specific topics. Most were related to exercise physiology, toxicology and the increasingly important topic of noise induced hearing loss. Lieutenant Colonels Ronnie Brown, Chris Callow and David Coombe, Majors Tim Finnegan and Ian Lambert all passed through during Colonel Harwood's tenure, as did Army medical officers from Australia and New Zealand. At the same time Colonel Peter Abraham was involved in human sleep deprivation trials with APRE's psychologists.

Since 1988 the pace of change within the service has been more than reflected at APRE. Lieutenant Colonel Chris Box took over from Colonel Harwood and continued the work on lower limb injuries. He moved after just over a year when Lieutenant Colonel Bill Freeland arrived and remained in post until the end of 1993. During his time an increased emphasis was given to teaching. Militarily important seminars on parachuting injuries and repetitive strain injuries to soldiers' feet were arranged and the teaching material for the PGMO course was completely rewritten with the help of the resident combat medical technicians, Corporals K Campbell and Dave Willis. Colonel John Richardson, Lieutenant Colonel Charles Batty and Majors Fiona Folkes and Chris Hands were all attached for short periods and, in the main, continued the work on noise induced hearing loss.

In mid 1993 the Military Advisor to the Director of APRE left and was not replaced. His work was redistributed and some of it fell to AOHRU, particularly that relating to the administration of the Military Field Trials Team. Lieutenant Colonel Bill Freeland departed in October 1993 on retirement and was not replaced until April 1994. This interregnum was filled by Major Nick Cooper, who kept the essential teaching, advice and administrative functions running.

I joined APRE in April 1994 with the task of integrating the RAMC element into DRA CHS. This has been a fascinating, if at times frustrating, process. At the time of APRE's incorporation into CHS, research was being undertaken into lower limb injuries (Major Jeremy Owen), the causes of medical downgrading (myself) and shift work (Major Louise Holden) with prospective studies involving heat illness and the toxic hazards of armoured fighting vehicles. The PGMO teaching is being reviewed to integrate it more closely with the rest of the course and to whatever tri-Service equivalent may be run in the future.

Supervision of postgraduate medical training is taking place both at DRA CHS for military and civilian personnel and also within some military posts in the Aldershot area. Interestingly this has included some work on smoking in the Army by Major Sean Drysdale which follows up some of the work done by Major General Crowdy. In addition, as has happened throughout APRE's existence, external teaching and committee work has been carried out on behalf of various parts of MoD.

The future is uncertain but the past would indicate that there is a place for uniformed RAMC input to Armed Forces human factors research. What is important is that human factors researchers tasked by MoD have access to medical officers who understand both the military and medical requirements. In order to be in that position medical officers should have undertaken some appropriate research themselves.

This article is of necessity brief. If anyone is intereste in following-up any particular aspect much materia exists. Particular thanks are due to Major Genera Crowdy, Brigadiers Worsley and Harwood and Dr Allan for their help in providing some fascinating backgroun information. Their contributions have been savaged and plagiarised and the author accepts full responsibility for the errors, omissions and biases. Although restricted quire deliberately to RAMC personnel, it would be quite wrong not to mention the determined and knowledgeable civilian scientific staff who carried out the bulk of the work at APRE (and who now carry it out at CHS) without whom it would have been impossible for the RAMC personnel to have functioned. 